\title{
28. MIDDLE PLIOCENE CHANGE IN PLANKTONIC FORAMINIFERAL FAUNA AT SITE 606 $^{1}$
}

\author{
Lisa M. Ehrmann, Massachusetts Institute of Technology \\ and \\ Lloyd D. Keigwin, Woods Hole Oceanographic Institution ${ }^{2}$
}

\begin{abstract}
A "total fauna" curve (Ruddiman, 1971) shows that surface water overlying DSDP Site 606 (central North Atlantic Ocean) cooled suddenly at $3.1 \mathrm{Ma}$, within the Mammoth paleomagnetic reversed interval. At that time, Globorotalia puncticulata, Neogloboquadrina pachyderma, and Globorotalia crassaformis increased and Globorotalia hirsuta, Globigerinoides sacculifer, and Sphaeroidinellopsis decreased in abundance. Oxygen isotope results for Globigerina bulloides do not indicate a "stepwise" cooling, but probably reflect small changes in continental ice volume. It is hypothesized that as annual average temperatures decreased, $G$. bulloides delayed its bloom from spring to summer to follow a preferred temperature habitat.
\end{abstract}

\section{INTRODUCTION}

This report examines planktonic foraminiferal faunal changes which occurred in the central North Atlantic Ocean at about $3 \mathrm{Ma}$. Middle Pliocene oceanographic events have been the focus of considerable attention since the study of Shackleton and Opdyke (1977), which argued that Northern Hemisphere ice sheets became extensive beginning at about 3.0 to $3.2 \mathrm{Ma}$. That study showed evidence that glaciation occurred several hundred thousand years earlier than the previous stable-isotope estimate of its inception at $\sim 2.5 \mathrm{Ma}$ (Devereux et al., 1970; Shackleton and Kennett, 1975). Many subsequent studies revealed a significant enrichment in ${ }^{18} \mathrm{O}$ in foraminiferal carbonate at $3.1 \mathrm{Ma}$, clearly marking that time as an important threshold in Pliocene climatic evolution (Keigwin and Thunell, 1979; Keigwin, 1982b; Hodell et al., 1983; Weissert et al., 1984). This event has also been associated with the evolution of Mediterranean climate on land (Suc, 1984) and at sea (Thunell, 1979).

Not all workers agree that the event at $3.1 \mathrm{Ma}$ was a permanent increase in continental ice volume. Backman (1979) first suggested that it might have been a cooling in the deep sea, since his revised biostratigraphy of North Atlantic DSDP sites suggested an initiation of ice-rafting at about $2.5 \mathrm{Ma}$. Similar views were also expressed by Prell $(1982 ; 1984)$ and Thunell and Williams (1983). Finally, Shackleton et al. (1984) published a detailed record of climatic change for the last $3.5 \mathrm{Ma}$ based on DSDP Hole 552A in the northeast North Atlantic Ocean. Oxygen isotope results from that hole revealed a minor enrichment in ${ }^{18} \mathrm{O}$ at $\sim 3.1 \mathrm{Ma}$, of comparable magnitude to other events earlier and later. At that location there appears to have been neither a major $\delta^{18} \mathrm{O}$ event nor a stepwise increase at $3.1 \mathrm{Ma}$.

\footnotetext{
${ }^{1}$ Ruddiman, W. F., Kidd, R. B., Thomas, E., et al., Init. Repts. DSDP, 94: Washington (U.S., Govt. Printing Office).

2 Addresses: (Ehrmann) E25-310B, Massachusetts Institute of Technology, Cambridge, MA 02139; (Keigwin) Woods Hole Oceanographic Institution, Woods Hole, MA 02543. Correspondence about this chapter and requests for reprints should be addressed to the second author.
}

Thus, considerable uncertainty exists about the deepsea record of climatic change at $3.1 \mathrm{Ma}$. Is the $\delta^{18} \mathrm{O}$ event at Hole $552 \mathrm{~A}$ absent because of the core disturbance, which prevented recognition of the Mammoth paleomagnetic event (Shackleton et al., 1984)? Is it a step-like increase at other locations, but not at Hole 552A? Is it larger in the Pacific than in the Atlantic? How much of the $\delta^{18} \mathrm{O}$ signal reflects temperature change and how much ice volume change? These are important and difficult questions to answer, and planktonic foraminiferal faunal results presented here, which suggest a step-like cooling, contribute to solution of only part of the puzzle.

DSDP Hole 606 was cored with the Advanced Piston Corer on the western flank of the Mid-Atlantic Ridge $\left(37^{\circ} 20.32^{\prime} \mathrm{N}, 35^{\circ} 29.99^{\prime} \mathrm{W}\right.$; water depth $\left.3007 \mathrm{~m}\right)$. Sediment from this site is well suited for the studying of middle Pliocene faunal events because of the excellent preservation of $\mathrm{CaCO}_{3}$ microfossils (owing to relatively shallow water depth), the outstanding continuous recovery, the sedimentation rate of nearly $4 \mathrm{~cm} / 10^{3}$ yrs., and the lack of sediment disturbance. All geomagnetic reversals through the upper Gilbert are recognized, though at the time of this writing they are only constrained to within $1.5-\mathrm{m}$ limits (Clement and Robinson, this volume). Furthermore, a detailed stable-isotope study of Site 606 benthic and planktonic foraminifers (Keigwin, this volume) affords precise correlation with the results obtained to the north (DSDP Hole 552A) by Shackleton et al. (1984).

\section{METHODS}

Samples of about $10 \mathrm{~cm}^{3}$ from Core 12 of Hole 606 were disaggregated in a hot solution of water and sodium metaphosphate and washed over a $63-\mu \mathrm{m}$ sieve. The coarse fraction was dried in an oven at $<50^{\circ} \mathrm{C}$, further sieved, and the fraction $>180 \mu \mathrm{m}$ was split with a microsplitter, aiming for a subsample of 300 whole specimens. All planktonic specimens were counted, and at least $98 \%$ were identified.

\section{RESULTS AND DISCUSSION}

Percent abundance data for planktonic foraminiferal species are presented in Table 1. Dominant faunal changes within the studied interval are an increase in the abun- 
Table 1. Site 606 faunal data (species abundance in percent) and ecological interpretation.

\begin{tabular}{|c|c|c|c|c|c|c|c|c|c|c|c|c|c|c|c|c|c|c|c|c|c|c|}
\hline \multirow[b]{2}{*}{$\begin{array}{c}\text { Sub-bottom } \\
\text { depth (m) }\end{array}$} & \multirow[b]{2}{*}{$\begin{array}{c}\text { Fragmented/ } \\
\text { whole } \\
\text { planktonic }^{a}\end{array}$} & \multirow[b]{2}{*}{$\begin{array}{l}\text { Benthic/ } \\
\text { whole } \\
\text { planktonic }\end{array}$} & \multicolumn{5}{|c|}{ "Cool" } & \multicolumn{12}{|c|}{ "Warm" } & \multicolumn{2}{|c|}{ "Other" } & \multirow[b]{2}{*}{$\begin{array}{l}\text { Total number } \\
\text { planktonics } \\
\text { in split }\end{array}$} \\
\hline & & & 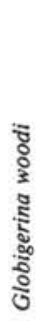 & 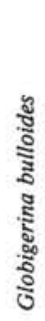 & 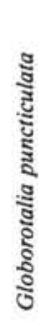 & 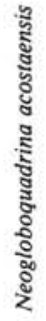 & 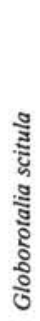 & 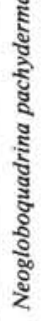 & 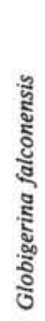 & 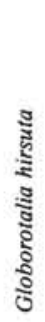 & 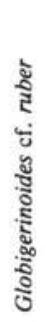 & 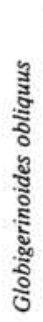 & 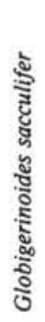 & 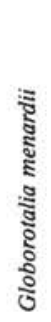 & 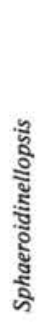 & 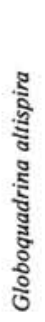 & $\begin{array}{l}\text { के } \\
\text { है } \\
\text { है } \\
5\end{array}$ & 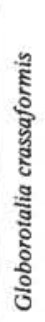 & 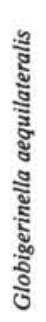 & 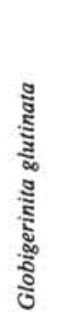 & 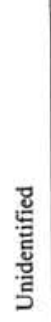 & \\
\hline 102.25 & 0.22 & 0.003 & 7 & 22 & 14 & 3 & 1 & 1 & 12 & 2 & 8 & 4 & 1 & $-^{b}$ & 2 & 6 & - & 12 & 1 & 3 & 2 & 388 \\
\hline 102.75 & 0.12 & 0.003 & 11 & 17 & 21 & 1 & - & 2 & 8 & - & 11 & 6 & 1 & 1 & 1 & 2 & - & 15 & 1 & 1 & 1 & 664 \\
\hline 103.25 & 0.12 & 0.006 & 3 & 16 & 27 & 3 & - & 2 & 10 & - & 11 & 7 & 2 & - & 1 & 3 & - & 11 & 2 & 2 & $i$ & 491 \\
\hline 103.55 & 0.11 & 0.005 & 6 & 24 & 15 & 5 & 1 & 2 & 6 & 4 & 11 & 8 & 5 & - & 1 & 1 & - & 5 & 1 & 4 & 1 & 392 \\
\hline 103.75 & 0.13 & 0.003 & 11 & 24 & 11 & 4 & - & 3 & 10 & 11 & 8 & 5 & 2 & - & $i$ & 2 & - & 3 & - & 2 & - & 962 \\
\hline 104.05 & 0.08 & 0.003 & 9 & 12 & 19 & 8 & - & - & 14 & 18 & 8 & 4 & - & - & - & 4 & - & - & 2 & 2 & - & 330 \\
\hline 104.15 & 0.09 & 0.007 & 10 & 22 & 20 & 4 & - & - & 7 & 21 & 5 & 6 & - & - & - & 3 & - & - & - & - & - & 289 \\
\hline 104.25 & 0.07 & 0.004 & 12 & 25 & 17 & 6 & - & - & 13 & 16 & 2 & - & 1 & - & - & - & - & 1 & - & 3 & - & 249 \\
\hline 104.35 & 0.11 & 0.015 & 5 & 29 & 17 & 1 & - & 6 & 9 & 19 & 4 & 3 & - & - & - & - & - & 1 & 1 & 3 & - & 1031 \\
\hline 104.55 & 0.10 & 0.009 & 11 & 30 & 10 & 9 & - & - & 11 & 16 & 4 & 1 & - & - & - & 4 & - & - & 1 & 2 & - & 219 \\
\hline 104.75 & 0.09 & 0.014 & 10 & 23 & 1 & 7 & 1 & 1 & 10 & 19 & 8 & 7 & 4 & - & 1 & 1 & - & 2 & 3 & 1 & 1 & 490 \\
\hline 104.95 & 0.16 & 0.015 & 11 & 17 & 2 & 8 & - & - & 9 & 29 & 7 & 4 & 7 & - & 2 & - & - & - & 2 & 2 & - & 271 \\
\hline 105.25 & 0.01 & 0.012 & 6 & 24 & - & 4 & - & 1 & 7 & 29 & 8 & 6 & 5 & 1 & 2 & - & 2 & 2 & - & 2 & 1 & 562 \\
\hline 105.45 & 0.13 & 0.010 & 9 & 16 & 15 & 3 & - & 1 & 9 & 24 & 8 & 7 & 3 & 1 & 4 & 1 & - & 1 & 1 & 1 & - & 197 \\
\hline 105.75 & 0.24 & 0.017 & 5 & 27 & 3 & 5 & 1 & - & 12 & 9 & 12 & 6 & 5 & - & - & 2 & - & 7 & 2 & 1 & 2 & 241 \\
\hline 106.25 & 0.13 & 0.000 & 13 & 19 & 1 & 6 & - & - & 12 & 12 & 11 & 7 & 2 & 1 & 2 & 12 & - & - & 1 & 1 & 1 & 178 \\
\hline 106.35 & 0.11 & 0.010 & 13 & 19 & 1 & 7 & - & - & 14 & 14 & 10 & 5 & - & - & 1 & 13 & 1 & - & 1 & 1 & - & 278 \\
\hline 106.75 & 0.12 & 0.014 & 13 & 18 & i & 10 & - & - & 9 & 19 & 12 & 5 & 2 & 2 & 5 & 1 & 1 & - & 2 & 1 & 1 & 353 \\
\hline
\end{tabular}

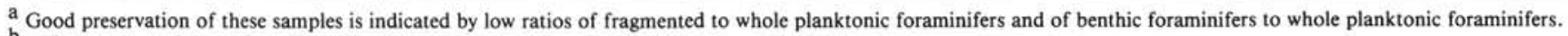
$\mathrm{b}-$ indicates species not found in split.

dance of Globorotalia puncticulata, Neogloboquadrina pachyderma, and Globorotalia crassaformis, and a lesspronounced decrease in the abundance of Globorotalia hirsuta, Globigerinoides sacculifer, and Sphaeroidinellopsis spp. Rather than base our interpretation on just one or a few taxa, we use the "total fauna" approach of Ruddiman (1971), for which the excess percentage of cool-water over warm-water faunal elements is shown in Figure 1. Table 1 also summarizes our assumptions about the temperature preferences of the middle Pliocene fauna, which rely heavily on the core-top distribution of Holocene species (Kipp, 1976) and the plankton tow data summarized by Bé (1977). We assume, further, that extinct species had approximately the same ecological requirements as their modern descendants or nearest relatives, recognizing that this avoids the fundamental question of why they are extinct. Thus, we assume that Neogloboquadrina acostaensis and $G$. puncticulata were relatively cool-water species and that Globigerinoides obliquus and Sphaeroidinellopsis spp. indicate warmer water.

The most significant result of the total-fauna analysis is that at about $104.6 \mathrm{~m}$ sub-bottom there is an abrupt shift to increased abundance upsection of cool-water species over previously dominant warm-water species. Peak abundance of cool-water species occurs at $104.4 \mathrm{~m}$ subbottom, where cool-water species exceed warm-water species by 20 to $30 \%$. Within the uncertainties of the limits of the Mammoth geomagnetic event, this faunal turnover occurred at $3.1 \mathrm{Ma}$.

If further work shows the faunal turnover at $3.1 \mathrm{Ma}$ to have been a ubiquitous feature in the central North

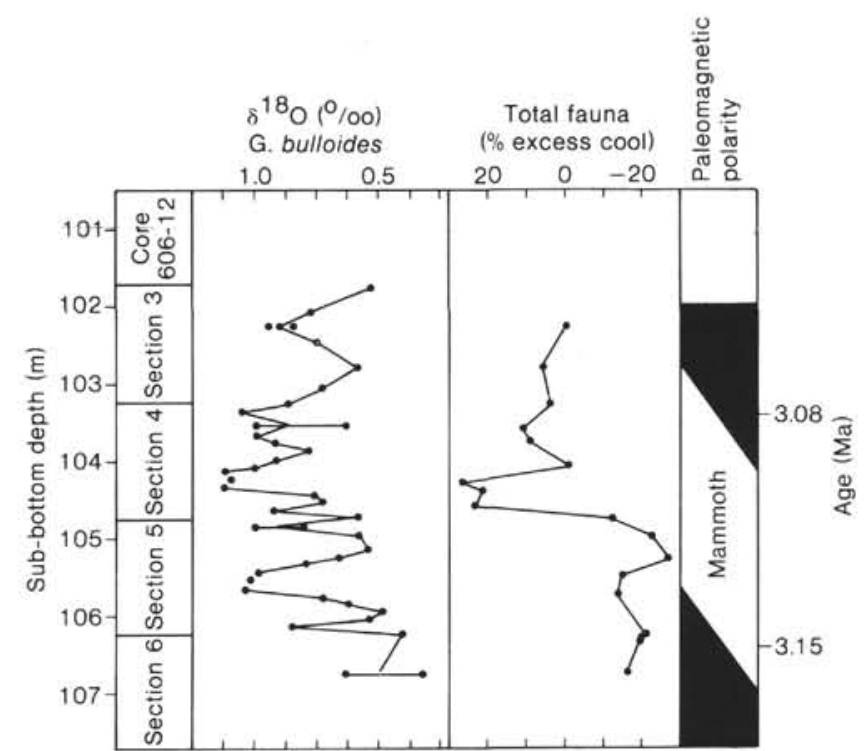

Figure 1. Faunal results of this study compared with oxygen isotope results (Keigwin, this volume) and paleomagnetic interpretation (Clement and Robinson, this volume). The "total fauna" curve suggests pronounced cooling of surface waters beginning at 3.1 Ma, whereas the oxygen isotope record of $G$. bulloides probably responds more to minor changes in continental glaciation.

Atlantic, then this event probably marks the establishment of modern biogeographic patterns. Site 606 underlies the boundary between the modern Transitional Surface Water mass, marked today by relatively abundant Globorotalia inflata, and the Subtropical Water mass, marked by warmer-water species (Bé and Tolderund, 1971; 
Kipp, 1976). G. inflata s.s. evolved from G. puncticulata by about $3 \mathrm{Ma}$ (Berggren, 1977), but it is not present in our samples. Most specimens of $G$. puncticulata below Section 606-12-2 are advanced forms but are mostly fourchambered rather than the typical three-chambered $G$. inflata. Thus, the available faunal evidence indicates that surface waters of the central North Atlantic cooled and the Transitional Faunal Province expanded before the evolution of the species ( $G$. inflata) that distinquishes that province today.

Most workers would agree that cooling events during the Pliocene led to modern climatic patterns, but few studies have presented quantitative planktonic foraminiferal results in sufficient detail to determine the exact timing and extent of these changes. For example, cooling surface water in the middle Pliocene of the Panama Basin was inferred by Keigwin (1976), and a brief cool event elsewhere in the Pacific was identified at 3.0 to 3.2 Ma by Keller (1979). Studies in the Mediterranean region have also demonstrated quantitative foraminiferal evidence of middle Pliocene cooling (Thunell, 1979; Zachariasse and Spaak, 1983). Zachariasse and Spaak (1983) describe three Pliocene intervals marked by abundant $G$. puncticulata or G. inflata. The middle event probably began at about 3.1 or $3.2 \mathrm{Ma}$, since it was followed shortly by the extinction of Sphaeroidinellopsis (dated at $3.05 \mathrm{Ma}$ in the Caribbean; Keigwin, 1982a), and therefore is probably correlative with our evidence of cooling. Abundance of the G. inflata group in Pliocene Mediterranean and nearby Atlantic sediments is associated by Zachariasse and Spaak (1983) with intensification of the cool eastern boundary current in the North Atlantic. Presumably this current system, at times when it was more intense, carried more of its $G$. inflata group fauna southward toward the Mediterranean.

CLIMAP (Climate/Long Range Investigation Mapping and Prediction) results showed that surface-water temperature anomalies and foraminiferal faunal changes were greater around the subtropical gyre margins than within the gyres (McIntyre et al., 1976). Temperatures at latitudes between the equator and $42^{\circ} \mathrm{N}$ were relatively stable. Assuming that oceanic circulation in the middle Pliocene was similar to that of today, it is seen that the faunal change at $3.1 \mathrm{Ma}$ was particularly dramatic, and probably resulted from significant cooling.

It is suprising that such a large, stepwise faunal change is not reflected in the oxygen isotope record of near-surface-dwelling planktonic foraminifers (Fig. 1). $\delta^{18} \mathrm{O}$ of G. bulloides is known to increase systematically with temperature decrease in upwelling regions. This has been shown regionally in core tops across a $4^{\circ} \mathrm{C}$ gradient (Prell and Curry, 1981) and in a high-resolution time series of the last several decades, where sea surface temperature has varied by $2^{\circ} \mathrm{C}$ (Dunbar, 1983).

Two hypotheses can account for our observation of faunal change in the absence of oxygen isotope change. The first is that there was simply no cooling at all and some unknown factor controlled the species abundance changes at 3.1 Ma. We reject this explanation because of independent evidence of cooling at this time from the terrestrial record (Suc, 1984), as well as nannofloral evi- dence from Site 606 and cores from other sites (Backman, this volume; Backman and Shackleton, 1983/84). Backman and Pestiaux (this volume) find a decrease in Discoaster abundance during the Mammoth Event at Site 606 , which they interpret as indicating cooling of surface waters. A similar pattern was also found in an equatorial Pacific core (Backman and Shackleton, 1983/84).

The second hypothesis, which we favor, is that there was indeed a surface-water cooling at $3.1 \mathrm{Ma}$, but that the ecological requirements of $G$. bulloides render it unrecognizable using the oxygen isotope method. For example, this species may adjust its season of growth to maintain a preferred temperature. It is well known that at subtropical locations in the western North Atlantic, G. bulloides proliferates late in winter (Tolderlund and Bé, 1971; Deuser, et al., 1981). At higher latitudes in the North Atlantic, however, maximum test production occurs in late summer and fall (Tolderlund and Bé, 1971). Thus, as the surface water over Site 606 cooled at $3.1 \mathrm{Ma}$, G. bulloides could have shifted its bloom from the spring to the summer without recording a decrease in average annual temperature in its oxygen isotope ratio. This "seasonality" hypothesis is consistent with the benthic and planktonic $\delta^{18} \mathrm{O}$ results for Site 606 (Keigwin, this volume). Near and during the Mammoth Event, virtually all of the $\delta^{18} \mathrm{O}$ variability in $G$. bulloides can be accounted for by ice-volume changes, since the oxygen isotope ratios of G. bulloides and Planulina wuellerstorfi covary in this interval. In fact, the small increases in $\delta^{18} \mathrm{O}$ of $G$. bulloides at about 102.3, 103.5, 104.3, and $105.6 \mathrm{~m}$ subbottom are matched by larger increases in the benthic record, suggesting that the deep sea cooled by 1 or $2^{\circ} \mathrm{C}$ during these minor glaciations.

\section{CONCLUSIONS}

Counts of middle Pliocene planktonic foraminiferal species reveal a pronounced cooling event in the central North Atlantic at 3.1 Ma. Evidence for this is increased abundance of Globorotalia puncticulata and Neogloboquadrina pachyderma and decreased abundance of Globorotalia hirsuta, Globigerinoides sacculifer, and Sphaeroidinellopsis. These faunal changes represent the replacement of a warm-water fauna by the Pliocene equivalent of the modern Transitional Fauna.

\section{ACKNOWLEDGMENTS}

We thank C. E. Franks and M. Poag for technical assistance in the laboratory and Harold Andrews and R. G. Fairbanks for helpful discussions. D. Lazarus and R. C. Thunell provided helpful criticism of the manuscript. This research was supported by NSF grant OCE 8308893. This is WHOI Contribution No. 5909.

\section{REFERENCES}

Backman, J., 1979. Pliocene biostratigraphy of DSDP Sites 111 and 116 from the North Atlantic Ocean and the age of Northern Hemisphere glaciation. Stockholm Contrib. Geol., 32:115-137.

Backman, J., and Shackleton, N. J., 1983/84. Quantitative biochronology of Pliocene and early Pleistocene calcareous nannofossils from the Atlantic, Indian and Pacific oceans. Mar. Micropaleontol., 8:141-170.

Bé, A. W. H., 1977. An ecological, zoogeographic and taxonomic review of Recent planktonic foraminifera. In Ramsay, A. T. S. (Ed.), Oceanic Micropaleontology (Vol. 1): London (Academic Press), 1100. 
Bé, A. W. H., and Tolderlund, D. S., 1971. Distribution and ecology of living planktonic foraminifera in surface waters of the Atlantic and Indian oceans. In Funnell, B. M., and Riedel, W. R. (Eds.), Micropaleontology of the Oceans: London (Cambridge University Press), pp. 105-149.

Berggren, W. A., 1977. Late Neogene planktonic foraminiferal biostratigraphy of the Rio Grande Rise (South Atlantic). Mar. Micropaleontol., 2:265-313.

Deuser, W. G., Ross, E. H., Hemleben, C., and Spindler, M., 1981 Seasonal changes in species composition, numbers, mass, size and isotopic composition of planktonic foraminifera settling into the deep Sargasso Sea. Palaeogeogr., Palaeoclimatol., Palaeoecol., 33: 103-127.

Devereux, I., Hendy, C. H., and Vella, P., 1970. Pliocene and early Pleistocene sea temperature fluctuations, Mangaopari Stream, New Zealand. Earth Planet. Sci. Lett., 8:163-168.

Dunbar, R. B., 1983. Stable isotope record of upwelling and climate from Santa Barbara Basin, California. In Thiede, J., and Suess, I. (Eds.), Coastal Upwelling (part B): Sedimentary Records of Ancient Coastal Upwelling: New York (Plenum Press), pp. 217-246.

Hodell, D. A., Kennett, J. P., and Leonard, K. A., 1983. Climatically induced changes in vertical water mass structure of the Vema Channel during the Pliocene: Evidence from Deep Sea Drilling Project Holes 516A, 517 and 518. In Barker, P. F., Carlson, R. L., Johnson, D. A., et al., Init. Repts. DSDP, 72: Washington (U.S. Govt. Printing Office), 907-919.

Keigwin, L. D., Jr., 1976. Late Cenozoic planktonic foraminiferal biostratigraphy and paleoceanography of the Panama Basin. Micropaleontology, 22:419.

1982a. Basis for age assignments at Deep Sea Drilling Project Sites 502-503. In Prell, W. L., Gardner, J. V., et al., Init. Repts. DSDP, 68: Washington (U.S. Govt. Printing Office), 493-495. 1982b. Isotopic paleoceanography of the Caribbean and east Pacific: Role of Panama uplift in late Neogene time. Science, 217: 350-353.

Keigwin, L. D., Jr., and Thunell, R. C., 1979. Middle Pliocene climatic change in the western Mediterranean from faunal and oxygen isotopic trends. Nature, 282:294-296.

Keller, G., 1979. Late Neogene paleoceanography of the North Pacific DSDP Sites 173, 310 and 296. Mar. Micropaleontol., 4:159-172.

Kipp, N., 1976. New transfer function for estimating past sea-surface conditions from sea-bed distribution of planktonic foraminiferal assemblages in the North Atlantic. Mem. Geol. Soc. Am., 145: 3-41.

McIntyre, A., Kipp, N. G., Bé, A. W. H., Crowley, T. C., Kellogg, T., et al., 1976. Glacial North Atlantic 18,000 years ago: A CLIMAP Reconstruction. In Cline, R. M., and Hays, J. D. (Eds.), Investigation of Late Quaternary Paleoceanography and Paleoclimatology: Boulder (Geol. Soc. Am.), pp. 43-76.
Prell, W. L., 1982. A re-evaluation of the initiation of Northern Hemisphere glaciation at 3.2 MY: New isotopic evidence. Geol. Soc. Am. Annu. Meeting, New Orleans, Abstr. Progr., p. 592. 1984. Covariance patterns of foraminiferal $\delta^{18} \mathrm{O}$ : An evaluation of Pliocene ice volume changes near 3.2 million years ago. Science, 226:692-694.

Prell, W. L., and Curry, W. B., 1981. Faunal and isotopic indices of monsoonal upwelling: Western Arabian Sea. Oceanol. Acta, 4(1): 91-98.

Ruddiman, W. F., 1971. Pleistocene sedimentation in the equatorial Atlantic: Stratigraphy and faunal paleoclimatology. Geol. Soc. Am. Bull., 82:283-302.

Shackleton, N. J., Backman, J., Zimmerman, H., Kent, D. V., Hall, M. A., et al., 1984. Oxygen isotope calibration of the onset of icerafting and history of glaciation in the North Atlantic region. $\mathrm{Na}$ ture, 307:620-623.

Shackleton, N. J., and Kennett, J. P., 1975. Late Cenozoic oxygen and carbon isotopic changes at DSDP Site 284: Implications for glacial history of the Northern Hemisphere and Antarctica. In Kennett, J. P., Houtz, R. E., et al., Init. Repts. DSDP, 29: Washington (U.S. Govt. Printing Office), 801-807.

Shackleton, N. J., and Opdyke, N. D., 1977. Oxygen isotope and paleomagnetic evidence for early Northern Hemisphere glaciation. Nature, 270:216-219.

Suc, J.-P., 1984. Origin and evolution of the Mediterranean vegetation and climate in Europe. Nature, 307:429-432.

Thunell, R. C., 1979. Pliocene-Pleistocene paleotemperature and paleosalinity history of the Mediterranean Sea: Results from DSDP Sites 125 and 132. Mar. Micropaleontol., 4:173-187.

Thunell, R. C., and Williams, D. F., 1983. The stepwise development of Pliocene-Pleistocene paleoclimatic and paleoceanographic conditions in the Mediterranean: Oxygen isotopic studies of DSDP Sites 125 and 132. Utrecht Micropaleontol. Bull., 30:111-127.

Tolderlund, D. S., and Bé, A. W. H., 1971. Seasonal distribution of planktonic foraminifera in the western North Atlantic. Micropaleontol., 17:297-329.

Weissert, H. J., McKenzie, J. A., Wright, R. C., Clark, M., Oberhänsli, H., et al., 1984. Paleoclimatic record of the Pliocene at Deep Sea Drilling Project Sites 519, 521, 522 and 523 (central South Atlantic). In Hsü, K. J., La Brecque, J. L., et al., Init. Repts. DSDP, 73: Washington (U.S. Govt. Printing Office), 701-715.

Zachariasse, W. J., and Spaak, P., 1983. Middle Miocene to Pliocene paleoenvironmental reconstruction of the Mediterranean and adjacent Atlantic Ocean: Planktonic foraminiferal record of Southern Italy. Utrecht Micropaleontol. Bull., 30:91-110.

Date of Initial Receipt: 9 November 1984

Date of Acceptance: 6 March 1985 